\title{
VOICES OF PRE-SERVICE ENGLISH TEACHERS: REFLECTING MOTIVATIONS DURING PRACTICUM LEARNING
}

\author{
Paulus Kuswandono \\ (kuspbi@gmail.com) \\ Universitas Sanata Dharma \\ Jl. Affandi (Gejayan) Mrican, Tromol Pos 29, Yogyakarta, Indonesia 55002
}

\begin{abstract}
After Dewey (1933) and Schön (1983, 1987), education scholars began to look further at the concepts of reflection for learning. Following these concepts, there have been plenty of studies on reflection, particularly those discussing teachers' classroom experiences and their endeavour to develop professional skills. However, educational practitioners in Indonesia (as in the rest of the world) often criticise preservice teachers' (PSTs) lack of content knowledge, which they claim should be 'prioritised' during a teacher education course. Such pressing situations may have made it difficult to model or experience reflective practice. Against these odds, this research paper addresses issues related to the identity and professional development of thirteen English PSTs during their campus and school-based practicum in an Indonesian university. This study collected empirical data through PSTs' reflective journals, questionnaires, individual interviews, focus group discussion, and autobiography. The study examines problems encountered by PSTs, namely their motivations to become teachers. This study signifies that teacher education needs to provide more reflective dialogues to shape PSTs' identity and professionalism.
\end{abstract}

Keywords: pre-service teachers (PSTs), motivation, reflective practice, practicum, identity

In this paper, I report and discuss how thirteen preservice teachers (PSTs) in Guru University in Indonesia describe themselves in relation to their professional identity through reflective practice during their campus-based practicum. The view of professional identity in this study can be likened to "stories" of our life, stories which we repeatedly tell to others and to ourselves regarding who 
we are. These stories reflect what we believe, feel, as well as our standpoint in the teaching discourse. As Connelly and Clandinin $(1998,2000)$ advocate, our identities constitute the stories we live by, or what they rather call an "ontology of experiences" (Clandinin, 2007, p. 40) wherein one lived experience is enriched by the other experience, and is going on to lead to further experiences. This notion brings forward an idea that within the context of becoming a teacher, Volkmann and Anderson (1998) view professional identity as an interplay state of disequilibrium and equilibrium, and what Beijaard, et al. (2004) refer to as an ongoing process of integrating self as a person within the profession of becoming and being a teacher (c.f. Chong \& Low, 2009; Schepens, Aelterman, $\&$ Vlerick, 2009). The on-going process of shaping professional identity often requires teachers to interpret and reinterpret their experiences through continuous reflection and is "continually being informed, formed, and reformed as individuals develop over time and through interaction with others" (Cooper \& Olson, 1996, p. 80). Therefore, it is obvious that the role of reflection in shaping PSTs' identity in this study is crucial, especially in the stage of becoming a teacher.

If the term reflection is traced back from its root, it has actually been around in education for almost 100 years since Dewey (1933), whose concept is subsequently developed by Schön $(1983,1987)$. In educational contexts, the idea from Dewey and Schön centers around the values of reflection, in that teachers need to stop and think of their actions by considering the values of practices and theories which underline their actions. This is to ensure that teachers, particularly novice teachers, engage themselves for continual learning. In this study, PSTs' reflections focus on how they perceive and make meaning of education, and they show (consciously or unconsciously) how their understandings of education are mediated by various cultural traditions drawn from their family, from social and political dynamics, as well as from their own experience of learning in schools (cf. Alsup, 2006). It is for this reason that during their practicum, PSTs need to be equipped with reflective skills, as Walkington (2005) clearly underlines: "reflective practice is promoted as crucial and its development is the responsibility of all teacher educators - both at university and in the schools" (p. 53). Meanwhile, the method of suggesting reflection for PSTs has been quite varied, such as individual reflection through 
writing reflective journals; creating an artefact such as collage (McDermott, 2002); and PST's reflection facilitated by a mentor, or social reflection which is done by peers in a group. However, the most common one used generally by teacher educators is the structured and guided questions to facilitate the students' reflection (e.g., Johns \& Marlin, 2010; Nolan, 2008).

Through PSTs' reflections, this study attempts to answer one main research question, namely, how do pre-service English teachers describe themselves, their emerging professional identities, and their professional learning? While my study reveals some findings related to the influential aspects of PSTs' professional identity, such as the role of their religions and beliefs on becoming teachers, I limit the discussion in this paper on their motivations to become teachers by studying in the English Education Study Program (EESP).

\section{METHOD}

In order to answer the above question, I generated data using a number of methods, namely reflective journals, individual interviews, focus group discussions, and some autobiographical writing by the Pre-Service Teachers (PSTs). The PSTs were required to write in their reflective journals every week as part of Practice Teaching 1 course (PT1), which is essentially a microteaching class. The reflective journals contained descriptions of and reflections about their professional identity and learning. Some guidelines for these reflections were provided as reference for the PSTs (see 'Guiding Questions for PSTs' Weekly Reflection', in Appendix 1), but students were told these were not intended to be prescriptive. This means that they could discuss their experiences beyond the frames that the questions suggested, should it be necessary.

Next, to help me make meaning of the language and the ideas in the PSTs' reflections, I used the Bakhtinian notion of "double-voiced discourse" as explained by Morson and Emerson (1990, p. 150). I was interested in the often subtle differences between explicit and more refracted meanings, and how these combined together in the PSTs' narrative reflection of their experiences, where any single word can be seen as half someone else's and thus the process of meaning making in research requires the researcher to be aware of and sensitive to the ways words and voices dialogically interconnect. Subsequently, based on my reading of these PSTs' reflections, I carried out an individual in- 
terview with each PST in a classroom in Guru University. In conducting these interviews I drew on Mishler's (1991) idea of the interview as authentic social discourse, and this was helpful in understanding how my shared cultural context (as researcher and lecturer within this university) impacted upon each and every interview. Integral in this idea is viewing an interview as a natural conversation rather than an objective, positivistic type of a question-and-answer event. In this way, I attempted to establish dialogue with PSTs and draw out their understandings of their professional learning experiences, including any awareness of the theories that underpin these experiences and the practices that enact these theories.

At the end of the PT1 subject, the PSTs were invited to write an extended reflective autobiographical entry using the guiding questions provided (see Appendix 2). From this autobiographical writing, I sought to understand the different dimensions of the PSTs' educational experiences and the influence of key people around them in these experiences, including those from their childhood who they felt had influenced them to eventually enroll in the EESP. In representing these experiences, I have tried to make explicit my awareness that all these processes of writing about people's lives interact with each other and contribute to the act of "life making" (Bruner, 2004, p. 692) through the written word. Also at the end of the semester, I conducted a focus group discussion with the PSTs, where participants were free to speak in Indonesian and/or English as they were comfortable to do so.

As I mentioned in the early part of this paper, there were 13 PSTs participating in the study. To protect their privacy and to ensure that I abided by the ethical purposes of the research for the participants, I use pseudonyms to ensure their anonymity as can be seen in Appendix 3. The demographic information in that table shows the diversity of PSTs who agreed to participate in this study. The number of students who are enrolled in a PT1 class at Guru University is usually around 25 students. However, there were only 13 PSTs enrolled in the course since most PSTs who were required to take the course based on their academic year had taken it in the previous semester. The ratio of five females to eight males is fairly representative of the usual gender ratios in such classes in Indonesian faculties of education, from my experience. I include data in the column headed "initial aspiration" to show the variety of vocational aspirations the students had before entering into their teacher education 
course. It is worth noting that only two PSTs (Endang and Kresna) said explicitly that they had always wanted to pursue a career as an English teacher. The fact that so many PSTs in due course entered the EESP and struggled to make meaning of their identity may be related to the fact that their decision to pursue a teaching career was not one they expected to be making.

\section{FINDINGS AND DISCUSSION}

In this section, I discuss some aspects that are influential to the development of PSTs' motivation to undertake study in the EESP in the first place. A number of educational researchers agree that PSTs' initial motivations to become a teacher are crucial since these can inform their decision to remain in or leave the profession (Bruinsma \& Jansen, 2010; Chong \& Low, 2009; Richardson \& Watt, 2006), and in the course of pre-service study these motivations can provide a useful point of reference when the PSTs are reflecting on aspects of their emerging professional identify. What often emerges in their reflections is a growing awareness of the nature and role of culture and educational background in their sense of themselves as potential educators; indeed, much research has shown how these factors powerfully shape the ways in which PSTs across the world negotiate, construct and/or sometimes resist their pre-service teaching lived experiences.

\section{Becoming a Teacher: A Realistic Aspiration or Realising the Hopes of Others?}

As evident in the table presented in Appendix 3, the motivations of two PSTs, namely Endang and Kresna, to study in the EESP were more clearly established, compared to other PSTs. These two students had always wanted to be English teachers. However, other PSTs who had not always yearned to be teachers, explained to me that their interest in becoming a teacher was more likely to be because of their concern for education quality in their community.

Endang's decision to enrol in the EESP course was based not only on her liking the study of English, but also because she saw that making teaching her career would be a realistic option. Endang learnt from her sister that teachers were relatively well-paid in Indonesia, and that the Indonesia government was 
increasingly seeing the role of teachers as important (cf. Jalal et al., 2009). In her autobiographical piece, she wrote that she did not regret choosing the EESP, especially since "after graduating from the English Education, we can get a job as a teacher more easily than that of English Letters Study Program. Therefore, I chose English Education" (Endang, Autobiography). Endang appeared to have more determination from the start to be a teacher compared to the other PSTs.

Such determination was also evident in Kresna's expression when I asked about his aspiration. At one moment, Kresna gave the impression that he saw becoming a teacher as the only imaginable direction for him, as he explained in his interview with me: "Teaching skills are the only skills I have. What else can I do?" (Kresna, Interview 1). And yet at other times, he revealed that his interest in teaching also had something to do with his concern for his family, that is to say, because the teaching profession gave him more time to spend with his family. This family reason for choosing teaching as a career is common in other places across the world, such as in Australia (Richardson \& Watt, 2006; Sinclair, 2008; Williams \& Forgasz, 2009).

Nevertheless, some PSTs who did not seem to me to be fully committed to teaching at the time of the data collection mentioned that they were aware of a desperate need for quality teachers in their communities, and that this awareness had made them think again of themselves as a social being, in effect a citizen in these communities. Over time, for some PSTs, this awareness seemed to spark their motivation to become a teacher in the future. This is evident in Amanah's experiences, where reflections on such things motivated her to make inquiries as to whether or not she wished to become a teacher. When I prompted Amanah in our interview to explain this a little further, and asked whether she felt she was wholeheartedly willing to undergo the process to be educated as a teacher, she responded positively by referring to her social background. She said that she was concerned that children in her community did not receive a good education in their schools. Therefore, she felt moved to open up her house to those children and to teach them English. This gave her a sense of deep satisfaction in her heart which she explained after teaching them, "I found excitement becoming a teacher" (Amanah, Interview 1). Or, as it became clearer the longer I talked with her, she began to feel slightly interested to become a teacher. Amanah herself said later that she was not sure about her own 'grain' 
of interest in teaching, whether this came from a real motivation to be a teacher, or whether this was just a flash of enjoyment that came from talking in front of people. She admitted that she liked being the centre of attention. Amanah's experience, however, is authentic and representative of many others in two main respects: (1) becoming a teacher (or ultimately not to become a teacher) involves a long process; and (2) sometimes students enrolled in teacher education courses come to the end of their degree with still a degree of uncertainty as to whether they wanted to be a teacher or not.

Meanwhile, Shinta and Bram developed their motivation to be a teacher after they saw the poor practices of education in their own communities, which they felt resulted in students' low motivation for learning. For example, Shinta was moved to become a teacher because she observed an urgent need of teachers in her surroundings, prompting her to question herself, "Who will teach those students in my hometown if I myself do not want to be their teacher?" (Shinta, Interview 2). This inner voice served as a strong encouragement for her to continue studying in the EESP regardless of the difficulties she admitted having in the education study program. Meanwhile for Bram, although he said he did not want to become a teacher during the period of data collection, he acknowledged that he might change his mind one day. The faint possibility of his changing his mind primarily emanated from his concern for education in contemporary Indonesia. In his experience, many students in Indonesia did not have a high motivation for learning and, for him, this was a serious drawback of the Indonesian education system, as he explained:

If we asked all students from primary to senior high school level, how many of them truly liked English as a subject, only a few of them would possibly say they liked it. Consequently, I might want to become a teacher after I graduate. Although I do not want to become a teacher [at the moment], one day I may decide to become one, entirely because I feel I have responsibilities to make students who lack motivation to love English. (Bram, Interview 1)

The thought of social and educational problems appeared to be the main encouragement for some PSTs to mull over their path of life as a teacher. However, often this encouragement was obstructed by what Shinta described as the 'fear' of teaching. She often imagined what it would be like if she was not ac- 
cepted by her students, whereas being accepted by students was the most fundamental need for her as a teacher.

All PSTs expressed that their decision to study in the EESP was based on their love of the English language and mostly their decision to study teaching was supported by recommendations from people around them, such as friends, parents, teachers, or relatives. However, the fact that the EESP had led them to become a teacher had presented some of them with a difficult dilemma. Anton is a good example of this dilemma. He said in a focus group interview that, like so many of the PSTs who were participating in this study, he had no intention to become a teacher at all since he was only interested in the English language. Education as a discipline did not interest him. He recounted how he had attempted to convince himself that he would participate in the teacher education process although he still found that learning in the EESP was very hard. Having said that, he consoled himself by saying that after graduating, he would still be in a position to freely choose which path of life he wanted to pursue. Another student, Johan, agreed with Anton:

My motivation to study in the EESP is definitely not from the education aspect to be a teacher, but from the English language itself. In comparison to Maths, English is the only subject I have been good at since junior and senior high school. However, I realise I am now already in semester 9. I have to undergo this process wholeheartedly. (Johan, FGD 1)

Some PSTs went so far as to say that the process of studying the "mata kuliah pendidikan [education subjects]" in this English Education course made them depressed. Such was the case for Dewa, who explicitly linked his lack of interest in studying to this EESP course. He entered the EESP due to his mother's determination regardless of the fact that he was already accepted into an Information Technology Study Program. The Information Technology program had been his first choice of university courses. But without his knowledge or consent, his mother re-registered him for a test in the EESP. He remarked in an interview with me, somewhat despondently, that he sometimes could not believe that he had ended up studying in the EESP.

Sometimes I want to rebel. Why should I become an educator? I am aware that I am now in the EESP, in a teacher education course. However, sometimes I also 
feel that it is not me. It is as if I have become somebody else. I try to accept this and I have to force myself to slowly undergo the process. But to be honest, I can only undergo the process slowly in comparison to my friends. (Dewa, Interview 1)

Although the social, cultural, and educational backgrounds of the PSTs I interviewed were quite diverse, it seems that most have come to the EESP with one characteristic in common, a high interest in improving their English uncomfortably coupled with a low motivation to become an English teacher. Most PSTs expressed that their motivation to enrol in the EESP was either encouraged by their relatives such as parents or through seeing the EESP graduates as role models whom they thought lead a 'good life'.

Some PSTs admitted that their knowledge of the various duties of a teacher had made the teaching profession unattractive to them. To explore these sorts of views further, I also asked a question during a focus group discussion: "If the salary received by a teacher and another profession (unidentified) were the same, which profession would you choose?" The answers were somewhat mixed, as for instance in Andre's response: "I prefer not teaching, but still, I want to teach as not the main job because I do not like the study job [i.e., preparing materials and lesson plans]" (Andre, FGD 1). It was obvious in Andre's statement that teaching was somewhat interesting to him but not as a primary job. From his educational experiences, being a teacher is not challenging because most teachers seem to repeat the same lesson plans, year after year. For Andre, such a job was boring, "just repeating and repeating, nothing new. And I thought that is how teachers teach in Indonesia" (Andre, FGD 1). For Andre, success was not defined narrowly by the ability of a person to earn money, but from "the fulfillment of our desire and passion" (Andre, FGD 1). And based on his observations, the work of teachers did not inspire any passion in him. Although teaching was not his main aspiration, Andre described himself as a person who liked teaching because he felt that he had capabilities to be a good English teacher. However, he perceived that he needed to create new challenges for himself. For Andre, the teaching profession lacked dynamism and while the profession provided a secure job, the income was limited and the work was tedious. In short, it seemed that the prospect of being a teacher was strongly connected in Andre's mind with formality and restrictions. In fact, this was a 
common perception amongst PST participants in this study. Their approach to their teacher education course (in the EESP) was consistent with what Manara (2012) describes in her study of Indonesian teacher educators as just a "bus stop" (p. 188), at which they would be able to jump off later for another nonteaching career. They saw the EESP as a means to an end, and the end was not necessarily teaching.

\section{Critical Reviews on PSTs' Motivations}

I believe that the vocational motivations of the PSTs in this study could be classified into two broad categories: namely intrinsic motivation and extrinsic motivation. A student who showed intrinsic motivation to become a teacher usually spoke about the inherent values of a rewarding career or the job satisfaction of a teacher (Smethem, 2007), while those who seemed driven by extrinsic motivation tended to speak about incentives, job security and status, more time for families or "personal utility values" (Richardson \& Watt, 2006, p. 38). According to Bruinsma and Jansen (2010), continuous extrinsic motivation can influence teachers to stay or to leave the profession, depending on whether the extrinsic motivation is adaptive or maladaptive. Bruinsma and Jansen (2010) go on to explain that adaptive motivation can facilitate long-term and effective engagement in teaching, such as the prospect of making a good professional career in teaching. In contrast, maladaptive motivation "promotes superficial engagement" (Bruinsma \& Jansen, 2010, p. 185), for example when PSTs enter teacher education because their parents think that becoming a teacher is a good career for their son or daughter or because the students could not gain entry into their first choice of study. According to Bruinsma and Jansen's (2010) study, PSTs with low teacher self-efficacy usually have developed extrinsic maladaptive motives from early in their higher education study.

For this study of PSTs in education, I choose to define self-efficacy as referring to teachers' beliefs in their ability to "invest in teaching, the goals they set, their persistence when things do not go smoothly and their resilience in the face of setbacks" (Tschannen-Moran \& Hoy, 2007, p. 944). Such a definition already suggests ways in which PSTs' motivation and self-efficacy are interrelated: i.e., low motivation of a PST would arguably correlate with low or under-developed self-efficacy since efficacy is "a motivational construct" 
(Tschannen-Moran \& Hoy, 2001, p. 946). In Tschannen-Moran and Hoy's (2007) argument, it follows that low self-efficacy is quite common for novice teachers; these researchers see low self-efficacy as almost inevitable because the teachers are still inexperienced. Being inexperienced teachers, they may have low belief in what they are capable of when dealing with the problems and challenges in their teaching practice. Nevertheless, Tschannen-Moran and Hoy's (2007) research findings which claim a correlation between low selfefficacy beliefs and inexperienced teachers can suggest a somewhat slippery conclusion if read without understanding the whole research context.

The notion of being inexperienced teachers in relation with self-efficacy can be interpreted differently as far as my experience as a teacher educator is concerned. Some PSTs can show that they are actively engaged in their learning and practice to become a teacher, and their level of engagement is not diminished by their consciousness that they still have a lot to learn from their practices. If this perspective can be accepted, their active engagement and willingness to learn from their teaching experiences in the classroom and from other educational spaces can actually be representative of a highly developed sense of self-efficacy.

Looking into the PSTs' experiences, Endang's and Kresna's descriptions of their motivations suggest that their interest in a teaching career is characterised by a number of adaptive extrinsic motivation factors. In contrast, Dewa's motivation can be categorised as maladaptive extrinsic forms. The earlier intrinsic form of motivation as seen in Endang and Kresna includes their selfperceptions of their ability to teach well (to do the job well), their appreciation of the job security that teaching in Indonesia offers as well as the recent increases in teacher remuneration, and family reasons. Based on my conversation with Endang and Kresna alone, I sensed that there was a greater chance that they would stay in the profession as they described themselves being more determined to become a teacher than to enter other professions or do other work. In contrast, Dewa's decision to enrol in the EESP was driven by his wishes to please his parents when his first choice of study did not get approval from them (maladaptive extrinsic motivation). From my conversation with him, it was evident that he was struggling to understand his own identity as an educator; his learning experiences in teacher education also revealed the same stories. From his narratives, Dewa's experiences in some ways were similar to Jamie's in 
Britzman's (2003) Practice Makes Practice: "Being there, but not being who you are" (p. 102). If Jamie did not feel she could be a good teacher as she attempted to construct a teacher identity as expected by the traditional roles of teachers, Dewa felt the same way but perhaps more deeply. Being a teacher just did not excite him. Unless he had some more positive experiences in teacher education in the future which might encourage him to take up further challenges to become a teacher, it was quite likely that Dewa would not stay in the teaching profession after he graduated.

Meanwhile for Amanah, Bram, and Shinta, their 'slight' interest in teaching was apparently driven by what might be called intrinsic sources of motivation - that is, their aspiration to improve the current practices and conditions of education. Day (2004) would say they were identifying a strong connection with the "moral purpose" of teaching (p. 126). This type of motivation generally can engender more commitment to teaching than those motivated by pragmatic reasons (Chong \& Low, 2009). 'Moral purpose' has been claimed as positively affecting teachers' satisfaction in their professional work and tending to increase the likelihood of their remaining in the profession (Smethem, 2007). However, as Smethem maintains, the marketisation of education and the intensification of teachers' work in schools, in contrast, work together to increase the attrition rate of existing teachers and to diminish the resolve of new teachers to remain in the profession. In my extended conversation with those PSTs (Amanah, Bram, and Shinta), they showed they were aware of those challenges, particularly some aspects of the teachers' demanding workload. In the same vein, Russell, McPherson, and Martin (2001) warn that "when initial idealism and unchallenged images of self-as-teacher meet the daily demands of students, curriculum, and the social culture of the school, beginners often report an inability to cope with many essential elements of the job" (p. 41). In turn, this inability can engender self-doubt in themselves as prospective teachers. Likewise, PSTs may feel that they actually like the idea of contributing to the education of Indonesian students and to make valuable changes in the lives of the next generation of Indonesians. However, when they come to consider the day-byday work and duties of teachers, this seems to dampen their enthusiasm for becoming a teacher (cf. MacGregor, 2009). Although such workload of a teacher has been realised early during PSTs' teacher education, it would seem that this aspect is not fully reflected as parts of their step-by-step professional develop- 
ment, that is to say, viewing teachers' (administrative) duties more positively as an integral aspect on becoming teachers.

\section{CONCLUSIONS AND SUGGESTIONS}

I have shown in this paper that the motivation of many PSTs as they enter the teaching profession in Indonesia is likely to undergo a number of shifts and changes, influenced by numerous factors, such as the their views and beliefs on becoming teachers, the values of which are influenced by their social, educational, and family background. This includes their concern to improve the education quality in their societies. Although the willingness of most PSTs to become teachers is tentative (at best), they also spoke encouragingly about their willingness to participate in the process of becoming a teacher.

Nevertheless, I must say that based on the results of this study, it can be quite disheartening to realise that most participants seem to lack any intrinsic motivation to study in their teacher education courses, considering that they were entering the final stages of their final year of study. It does not bode well for their chances of developing the motivation and/or self-efficacy that they will require if they are to endure the difficulties they will encounter in their initial years of teaching. As evident in the description above, some PSTs did appear to have some interest in becoming a teacher, and yet they spoke and wrote as if they wanted to avoid becoming a professional teacher in an Indonesian school. It is interesting to note that in so many of their reflections on becoming a teacher, there was a lively tension between wanting and not wanting to be a teacher, depending on the way they perceived the work (and duties) of a teacher.

With the growing pragmatism in teacher education nowadays, such as infusing more technical skills to be teachers than the deeper conceptual knowledge on critical pedagogy to PSTs, the time allocated for reflecting, particularly on PSTs' motivation to become teachers, often becomes peripheral, or if at all, implemented as a mere pro-forma. This phenomenon poses a serious challenge for teacher education institutions. Perhaps it is not just a matter of teaching reflective practice more effectively. It may be that these institutions need to enroll PSTs who are genuinely motivated to enter a teaching profession 
or to offer more inspiring learning programs which can stimulate PSTs' motivation to take up the challenges on becoming a teacher.

Nevertheless, since vetting prospective students' motivations for entering a teacher education degree prior to their enrolment is not a common practice although at the time of writing this paper the Indonesian Government in 2015 is indeed considering scanning prospective students' motivations and personality types for enrolling in a teaching degree through Pendidikan Profesi Guru (PPG) - for the moment, the focus for university mentors, supervising teachers and whole teacher education institutions is to develop curriculum, pedagogy and mentoring programs which can enhance PSTs' motivations for their work as teachers. This can include building more dialogues through more effective reflective practices and through a more sustained focus on students' developing professional identity and professional learning.

\section{REFERENCES}

Alsup, J. (2006). Teacher identity discourses: Negotiating personal and professional spaces. New Jersey: Lawrence Erlbaum Associates, Inc.

Beijaard, D., Meijer, P. C., \& Verloop, N. (2004). Reconsidering research on teachers' professional identity. Teaching and Teacher Education, 20, 107-128.

Britzman, D. P. (2003). Practice makes practice: A critical study of learning to teach. Albany: State University of New York Press.

Bruinsma, M., \& Jansen, E. P. W. A. (2010). Is the motivation to become a teacher related to pre-service teachers' intentions to remain in the profession? European Journal of Teacher Education, 33(2), 185-200. doi: 10.1080/02619760903512927

Bruner, J. (2004). Life as narrative. [Article]. Social Research, 71(3), 691-710.

Chong, S., \& Low, E.-L. (2009). Why I want to teach and how I feel about teaching-formation of teacher identity from pre-service to the beginning teacher phase. Educ Res Policy Prac, 8, 59-72.

Clandinin, D. J. (2007). Handbook of narrative inquiry-mapping a methodology. Thousand Oaks, CA: Sage. 
Clandinin, D. J., \& Connelly, M. (1998). Stories to live by: Narrative understandings of school reform. Curriculum Inquiry, 28(2), 149-164.

Clandinin, D. J., \& Connelly, M. (2000). Narrative inquiry: Experience and story in qualitative research. San Francisco: Jossey-Bass.

Cooper, K., \& Olson, M. R. (1996). The multiple 'I's' of teacher identity. In M. Kompf, W. R. Bond, D. Dworet \& R. T. Boak (Eds.), Changing research and practice: Teachers' professionalism, identities and knowledge (pp. 78-89). London: Falmer Press.

Day, C. (2004). A passion for teaching. London: Routledge.

Dewey, J. (1933). How we think: A restatement of the relation of reflective thinking to the educative process. Boston: D.C. Heath and Company.

Jalal, F., Samani, M., Chang, M. C., Stevenson, R., Ragatz, A. B., \& Negara, S. D. (2009). Teacher certification in Indonesia: A strategy for teacher quality improvement. Jakarta: Departemen Pendidikan Nasional.

Johns, C., \& Marlin, C. (2010). Jane's rap: Guided reflection as a pathway to self as sacred space. In C. Johns (Ed.), Guided Reflection (pp. 236255). Oxford, U.K.: Wiley-Blackwell.

MacGregor, D. (2009, June-July). Identity formation: Influences that shape beginning teachers' professional identity: Crossing the border from pre-service to in-service teacher. Refereed paper presented at 'Teacher education crossing borders: Cultures, contexts, communities and curriculum' the annual conference of the Australian Teacher Education Association (ATEA), Albury, 28 June - 1 July.

Manara, C. (2012). Intercultural dialogue and English language teaching: Indonesian teacher educators' narratives of professional learning (Doctoral Dissertation, Monash University, Melbourne, Australia).

McDermott, M. (2002). Collaging pre-service teacher identity. Teacher Education Quarterly, 29(4), 53-68.

Mishler, E. G. (1991). Research interviewing: Context and narrative. Cambridge: Harvard University Press. 
Morson, G. S., \& Emerson, C. (1990). Mikhail Bakhtin: Creation of a prosaics. California: Stanford University Press.

Nolan, A. (2008). Encouraging the reflection process in undergraduate teachers using guided reflection. Australian Journal of Early Childhood, 33 (1), 31-36.

Richardson, P. W., \& Watt, H. M. G. (2006). Who chooses teaching and why? Profiling characteristics and motivations across three Australian universities. Asia-Pacific Journal of Teacher Education, 34(1), 27-56. doi: 10.1080/13598660500480290

Russell, T., McPherson, S., \& Martin, A. K. (2001). Coherence and collaboration in teacher education reform. Canadian Journal of Education/Revue canadienne de l'education, 26(1), 37-55.

Schepens, A., Aelterman, A., \& Vlerick, P. (2009). Student teachers' professional identity formation: between being born as a teacher and becoming one. Educational Studies, 35(4), 361-378.

Schön, D. A. (1983). The reflective practitioner: How professionals think in action. London: Temple Smith.

Schön, D. A. (1987). Educating the reflective practitioner. San Fransisco: Jossey-Bass Inc.

Sinclair, C. (2008). Initial and changing student teacher motivation and commitment to teaching. Asia-Pacific Journal of Teacher Education, 36(2), 79-104. doi: 10.1080/13598660801971658

Smethem, L. (2007). Retention and intention in teaching careers: Will the new generation stay? Teachers and Teaching, 13(5), 465-480. doi: 10.1080/13540600701561661

Tschannen-Moran, M., \& Hoy, A. W. (2001). Teacher efficacy: Capturing an elusive construct. Teaching and Teacher Education, 17(7), 783-805. doi: 10.1016/s0742-051x(01)00036-1

Tschannen-Moran, M., \& Hoy, A. W. (2007). The differential antecedents of self-efficacy beliefs of novice and experienced teachers. Teaching and Teacher Education, 23(6), 944-956. doi: 10.1016/j.tate.2006.05.003 
Volkmann, M. J., \& Anderson, M. A. (1998). Creating professional identity: Dilemmas and metaphors of a first-year chemistry teacher. Science \& education, 82(3), 293.

Walkington, J. (2005). Becoming a teacher: Encouraging development of teacher identity through reflective practice. Asia-Pacific Journal of Teacher Education, 33(1), 53-64.

Williams, J., \& Forgasz, H. (2009). The motivations of career change students in teacher education. Asia-Pacific Journal of Teacher Education, 37(1), 95-108. doi: 10.1080/13598660802607673

\section{APPENDIX 1: GUIDING QUESTIONS FOR PSTS' WEEKLY REFLECTION}

1. In what ways was this lesson successful? Why or why not?

2. What were the main strengths and/or weaknesses of the lesson?

3. Did the students learn what they were intended to learn?

4. Did the lesson address the students' needs?

5. Was the lesson at an appropriate level of difficulty?

6. Were all students involved in the lesson?

7. Did the lesson arouse students' interest in the subject matter?

8. Did I do sufficient preparation for the lesson?

9. Do I need to re-teach any aspect of the lesson?

10. What would be a suitable follow-up to the lesson?

11. Should I have employed alternative teaching strategies?

12. Will I teach the material in the same way (or differently) next time?

\section{APPENDIX 2: GUIDING QUESTIONS FOR WRITING PSTS'AUTO- BIOGRAPHY}

1. Could you describe how your immediate family (e.g. parents, brothers, or sisters) have contributed to your attitudes to and values on education?

2. Could you describe your education background?

3. Did you like your primary and secondary schools? Why or why not?

4. Who were your favourite teachers?

5. What were your favourite subjects in school?

6. Why do you want to be an English teacher?

7. Why do you think English is an important language?

8. What experiences of your professional learning are most valuable for you in your journey to become an English teacher? 
9. What particular aspects of being a good teacher do you believe you need to improve?

\begin{tabular}{|c|c|c|c|c|c|}
\hline No & Name & Gender & $\begin{array}{l}\text { University } \\
\text { Entrance }\end{array}$ & Age & Initial Aspiration \\
\hline 1. & Andre & $\mathrm{M}$ & 2006 & 22 & $\begin{array}{l}\text { Businessperson/ } \\
\text { artist }\end{array}$ \\
\hline 2. & Amanah & $\mathrm{F}$ & 2007 & 21 & Reporter \\
\hline 3. & Jelita & $\mathrm{F}$ & 2007 & 21 & Police \\
\hline 4. & Dewa & M & 2007 & 21 & Computer engineer \\
\hline 5. & Bram & M & 2005 & 23 & Book writer \\
\hline 6. & Anton & M & 2007 & 21 & $\begin{array}{l}\text { Editor in a publish- } \\
\text { ing company }\end{array}$ \\
\hline 7. & Andi & M & 2006 & 22 & $\begin{array}{l}\text { Editor in a publish- } \\
\text { ing company }\end{array}$ \\
\hline 8. & Joko & M & 2006 & 22 & Pharmacist \\
\hline 9. & Johan & M & 2006 & 22 & $\begin{array}{l}\text { Any profession } \\
\text { (except teaching) }\end{array}$ \\
\hline 10. & Endang & $\mathrm{F}$ & 2007 & 21 & English teacher \\
\hline 11. & Tari & $\mathrm{F}$ & 2007 & 21 & $\begin{array}{l}\text { General practition- } \\
\text { er }\end{array}$ \\
\hline 12. & Kresna & M & 2004 & 24 & English teacher \\
\hline 13. & Shinta & $\mathrm{F}$ & 2007 & 21 & businessperson \\
\hline
\end{tabular}

